\title{
Visual participatory as an analytic tool in managing violence among students in an urban secondary school in Zimbabwe
}

\author{
Ephias Gudyanga*, Nomsa Matamba \\ Midlands State University, Faculty of Education, Department of Educational Foundations, Management and Curriculum Studies, Gweru, \\ Zimbabwe
}

\author{
Email address: \\ gudyangae@msu.ac.zw (E. Gudyanga)
}

\section{To cite this article:}

Ephias Gudyanga, Nomsa Matamba. Visual Participatory as an Analytic Tool in Managing Violence among Students in an Urban Secondary School in Zimbabwe. International Journal of Secondary Education. Vol. 3, No. 1, 2015, pp. 8-15. doi: 10.11648/j.ijsedu.20150301.12

\begin{abstract}
The research was set to determine management practices of students' violent behaviour in an urban secondary school in Zimbabwe. The visual participatory methodology was used. Drawings and focus group discussions were the focal methods employed to generate data from 15 conveniently sampled participants over a period of two weeks. Involvement of parents, police, heads of schools and the perpetrators of violence were noted as violence reduction management practices. The school must adopt transparent and holistic approach where stakeholders including communities must engage with one another in an endeavour to eliminate violence. It was concluded that violence in schools can be eliminated.
\end{abstract}

Keywords: Violence, Visual Participatory, School, Behaviour

\section{Introduction}

Violence was noted to be high in the studied school [1]. Among other causative agents, the community in which school learners stay, was the main cause of violence [2]. The study, sought to determine how the same school could manage student violent behaviours.

\section{Background and Context}

\subsection{Measures Used to Monitor and Manage Violent Behaviour among Students}

Various measures have been put in place in order to manage violent behaviour among students in schools. Since violence comes in multiple forms, efforts by school personnel to prevent and mollify aggressive and violent behaviour are broad based [3].

A social environment that promotes safety and prevents violence as this might help in minimising violent behaviours among students is called for [4]. Creating a culture within the school that supports pro-social values and norms should be a priority. This will result in a school social climate that is characterised by respect, empathy and cooperation [3]. The climate according to [5] should create expectations for high academic standards, establish acceptable norms and rules of conduct that do not tolerate harassment, bullying, undesirable activities or other aggressive behaviour.

There is need to integrate school, family and community to prevent violence [6]. Family and community involvement is essential as this will enhance the effectiveness of such broadbased efforts. In Canada, the Ontario code of conduct which was designed by the Ministry of Education emphasised the importance of active parental involvement as a way of diffusing violent behaviour among students. Parents are invited to meet with school staff to develop a joint intervention plan and to support the disciplinary measures taken by school [7].

Mapping the schools' hotspots for violence incidence so that supervision could be concentrated in designated areas is critical [8]. Some schools according to [7] have closed all entrances into the school except for the main entrance to prevent unauthorised persons from coming into the school. [9] Pointed out that some schools have even hired security guards to patrol hallways and grounds while classes are in session.

Some schools according to researches done by [10] have procedures and policies to ensure the safety of students. For example, some schools have adopted a zero tolerance policy which can require expulsions of students who participate in 
violence or found with drugs or weapons. [11] Pointed out that some schools in Los Angeles make the students and their parents to sign a contract that stipulates that no child can be teased or ridiculed on the basis of his or her gender, family or academic performance. Other efforts by schools include the use of metal detectors examining students back packs or secret investigation for weapons or drugs.

There is need to use constructive discipline and teaching methods [3]. This includes keeping classroom rules positive and brief. Once rules are set educators should enforce them rigorously [12]. Having classroom rules enables the student to understand what kind of behaviour is expected from them and if these rules are distributed in print this will reinforce the understanding of students [13].

There is a need for teachers to use positive reinforcement like eye contact and using disciplinary measures that are educative and not punitive [13]. The school curriculum needs to include human rights and peace education where students will be taught their human rights as well as rights of their peers, teachers and family members [11]. The school timetable should be effectively implemented so that students will not find time to engage in anti-disciplinary activities.

As a way of monitoring and managing violent behaviour among students, [5] suggests that schools may provide counselling, psychological and social services that meet the physical, mental, emotional and social needs of students. Thus a student found in vicious aggressive behaviour must be referred to counselling. School psychologists according to [9] can assist in the selection and execution of well researched program that meets the needs of a specific school context.

The curricular should build student's resilience and help them to respond to life's challenges by building positive relationship with others [4]. Increased resilience reduces the likelihood of being involved in violence. Teachers who demonstrate pro-social behaviour provide guidance and other protection essential to increase student's resilience by showing a positive and alternative way of responding to life's challenges [14].

Schools should provide safe physical education and extracurricular physical activity programs as a way and managing violent behaviour among students [4]. These programs may provide a context in which youth may learn pro-social behaviour through the cooperation and teamwork that is learned in those contexts. According to [15] there is need for openness and information regarding school based violence. There is need to raise awareness and responsibility of both students and teachers regarding the types of violence in schools.

Cooperation work is said to have an effort on the development of a more amicable relationship between peers, reducing drastically the problems of victimisation [3]. Teachers need to encourage students to accept others and learning to listen to others and respect different opinions.

It is against this background that we sought to find out management practices which schools can engage in order to reduce violence amongst students.

The research question which guided this study was: how can violent behaviour among school students be minimised or eliminated?

\section{Methodology}

\subsection{Design and Participants}

Qualitative design was used. Visual participatory approach was considered suitable for the current research because it involves an interpretative naturalistic approach to the world [16]. This approach was motivated by an in depth inquiry to study a phenomenon in its natural setting as well as to interpret the phenomenon in terms of meaning and understandings constructed by people [17]. Visual participatory methodology tended to focus on a smaller population but probing deeper into a given problem [16, 18]. We adopted this methodological approach to understand students' perceptions on how schools can manage their students' violent behaviour. The main advantage of using visual participatory methodology was that it allowed open ended views to be formed therefore giving a more comprehensive understanding of participants and their experiences. We believed that by using visual participatory methodology to gather data, new insights and ideas would emerge from the study and this would bring about the greater understanding of violent behaviour management practices. The visual participatory methodology was both a design and an intervention [1]. The participants were most likely to end up changing their violent behaviours as they engaged with and reflect on their data.

The study was conducted in a secondary school located in Gweru high density suburb, in the Midlands province of Zimbabwe. The school was purposively selected because it was deemed to provide information concerning violent behaviour. In the selected school, we targeted Ordinary Level (O level) pupils. It was observed that violent behaviour was high among "O" Level students.

The students were the main source of information as they were the ones exhibiting violent behaviour. Continued reflection and reflexivity on ways to reduce violent behaviour could lead to behaviour change, hence this was the major justification of using visual participatory approach as an analytic tool.

A sample of 8 males and 7 females, (age range 14-18years), violent students was selected for both drawing method and focus group discussion (fgd). The names of these participants were supplied by both the head and deputy of the school. The participants were well known for their rampant violent behaviour in the school. The total number of 15 participants was justifiably considered adequate for the study. It was motivated by the need to have a detailed analysis of the phenomenon. Drawings had a minimum of two sessions, and fgd had one session of two hours each, over a period of two weeks.

\subsection{Method}

A range of visual methods could have been used for 
instance photography, painting, drawing and videography which produce data in material and visual form [18]. Visual participatory methodology give participants a sense of ownership over the research process and this makes them more likely to invest time and energy required to make the project a success $[18,19]$. Thus for the sake of the current study, we used drawings to solicit for information.

Drawings provided data in a fun and creative manner and participants actively engaged in the data collection process. The method brings out information that may remain hidden during verbal interviews [20]. Visual methods promote a more divert understanding of people, their life experiences and their perceptions than is possible with data controlled solely by the researcher [20].

Due to their engaging nature, participatory drawings emerge to be a highly efficient research strategy that is suitable when working with young people. The more involved the participants are in the different aspects of the research, the increased likelihood of long term personal benefits for those taking part [18]. Drawing can be used in order to understand how people see the world [21]. Discussions of the drawn images were done so that depiction of concepts, emotions and information in an expressive, empowering and personally relevant manner could be revealed.

The focus group discussions were conducted with the same students who were selected for drawings under participatory visual method. Focus group discussions were meant to enrich information obtained through drawings as students were able to explain some underlying factors driving violent behaviour among students at their school. We compiled notes during the discussion sessions. In order to avoid dominance by few individuals during the discussion sessions, we provided a platform for all individuals to participate without feeling intimidated or inferior by giving each participant the room to make contributions.

Ethical clearance was granted by the Gweru district education office in order for us to get into the selected school. We also sought permission from the school head to get the names of the 15 purported violent boys and girls. All participants gave their consent in writing before participating in the study. Confidentiality among participants was also granted in writing. In terms of anonymity effort was made to protect the identity of the participants by asking them not to write their names on the drawings but instead we used codes to refer to the participants. We did not name the school where the study was conducted for the same reason.

We explained the aims, purpose and method of the study to the participants. We also explained to the participants that when answering the prompt question, they were to do so in the form of a drawing. The participants answered one research question. The prompt statement was: With the aid of a drawing, show what could be done to effectively minimise or eliminate violent behaviour among students in your school.

The participants and the researchers had three sessions and in the first session, each participant answered the research question through construction of a drawing. During this first session we encouraged the participants to feel free to express themselves while they draw. In the second session, discussions were done with participants about each and every drawing so that meanings were deduced to address the research question. Participants would write onto the drawing the meaning of their drawing. Local language was used for clarity. Each participant led the discussion as he/she attempted to explain the meanings of his/her drawing.

It is during the third session that the participants discussed their drawings as a focus group. In the process the researchers were in a position to further understand what was being portrayed by the drawings. During this session, the participants took the lead again while the researchers listened and gave necessary guidance. We jotted down important information from the discussion and audio recorded everything that was discussed using mobile cell phones.

Coding and transcription of recorded data were done as part of analysis. Common themes were generated from transcriptions.

\section{Results}

The participants suggested different ways to manage violent behaviour in their school. The following themes were generated as suggestions made by participants to minimize or eliminate student's violent behaviour: involvement of parents, guidance and counselling lessons, involvement of the police, punishment, apologising to one another and involvement of class teachers.

Three participants suggested that students who exhibit violent behaviour should be given letters to invite their parents to the school so that they discuss their child's behavior with the Head of school. Students F, B and M had drawings showing the Head of school giving a letter to a student inviting the parents to the school (figure 1). Student $\mathrm{B}$ had this to say in local Shona language;

'Kana munhu arova umwe ngaapihwe tsamba yokudana vabereki'

Student B was simply saying that if a student is involved in any act of violence, the school authorities must invite his/her parents to the school.

During the focus group discussion, student $\mathrm{M}$ said that invitation of parents would help in the sense that the parents would monitor the students' behaviour at home and the teachers would monitor the students' behaviour at school. In that case, violence will be eliminated.

Three participants were of the view that sometimes there is need to involve the police. Student A believed that if one is disciplined by the police he or she will not repeat that behaviour. Student A had this to say in local Shona language;

'Kuenda kunorohwa kumapurisa nekuti ukasarohwa unofunga kuti zvinoita’

The participant was saying that students who exhibit violent behaviour must be handed over to the police for 
appropriate punishment. Student A was free to share her story with others during the focus group discussion. She told us that a month before this discussion, she was involved in a fight with another female student and were sent to the police by the head of the school where they were disciplined. She said that she is now afraid to fight with anyone else because she does not want to have that experience with the police again.

Four participants pointed out that guidance and counselling lessons may be used to manage and reduce violent behaviour among students. Student E had this to say during the focus group discussion;

\section{'Munhu kana aita mhosva ngaapiwe counselling'}

Student E pointing out those perpetrators of violence must be counselled. The majority of the participants concurred that counselling of students who were involved in violent behaviour was necessary as this might help them to change their behaviour. Student I pointed out that there was need for guidance and counselling teachers to teach students about violence, what it is, its causes, effects and the school's position regarding it. The participants were of the view that one might decide to change his or her behaviour or might choose not to be involved in any violent behaviour if he or she had some knowledge about it.

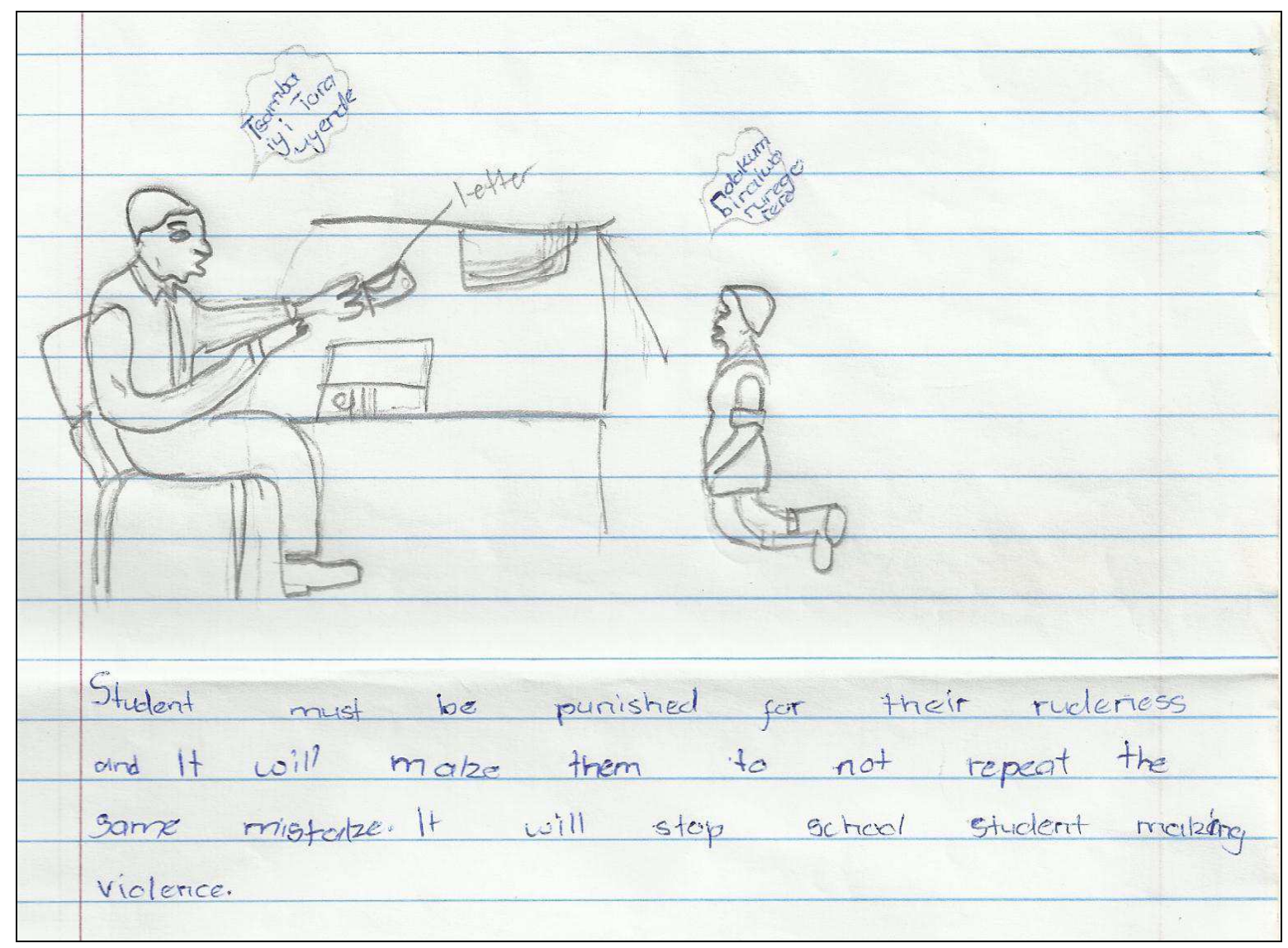

Figure 1. Female student being given a letter to invite her parents to school.

Two participants believed that those students who exhibited violent behaviour might desist from this practice if they were disciplined by the head of the school (figure 2). Student $\mathrm{C}$ said the following during the focus group discussion;

'Ukaziva kuti ndikatuka umwe ndinorohwa unobva watya kutuka vamwe'

The participant was saying that if students know that they can be disciplined by the school head for engaging in violent acts they are likely to refrain. Both student $\mathrm{C}$ and I pointed out that the head should beat up those who exhibited violent behaviour hence the drawing in figure 2 shows the school head and his deputy beating the violent students. The inscription says: 'vana vanorohwa nomukuru wechikoro nomutevedzeri wemukuru wechikoro nokuda kwokuti vanga varovana kusvika pakubudisana ropa" 


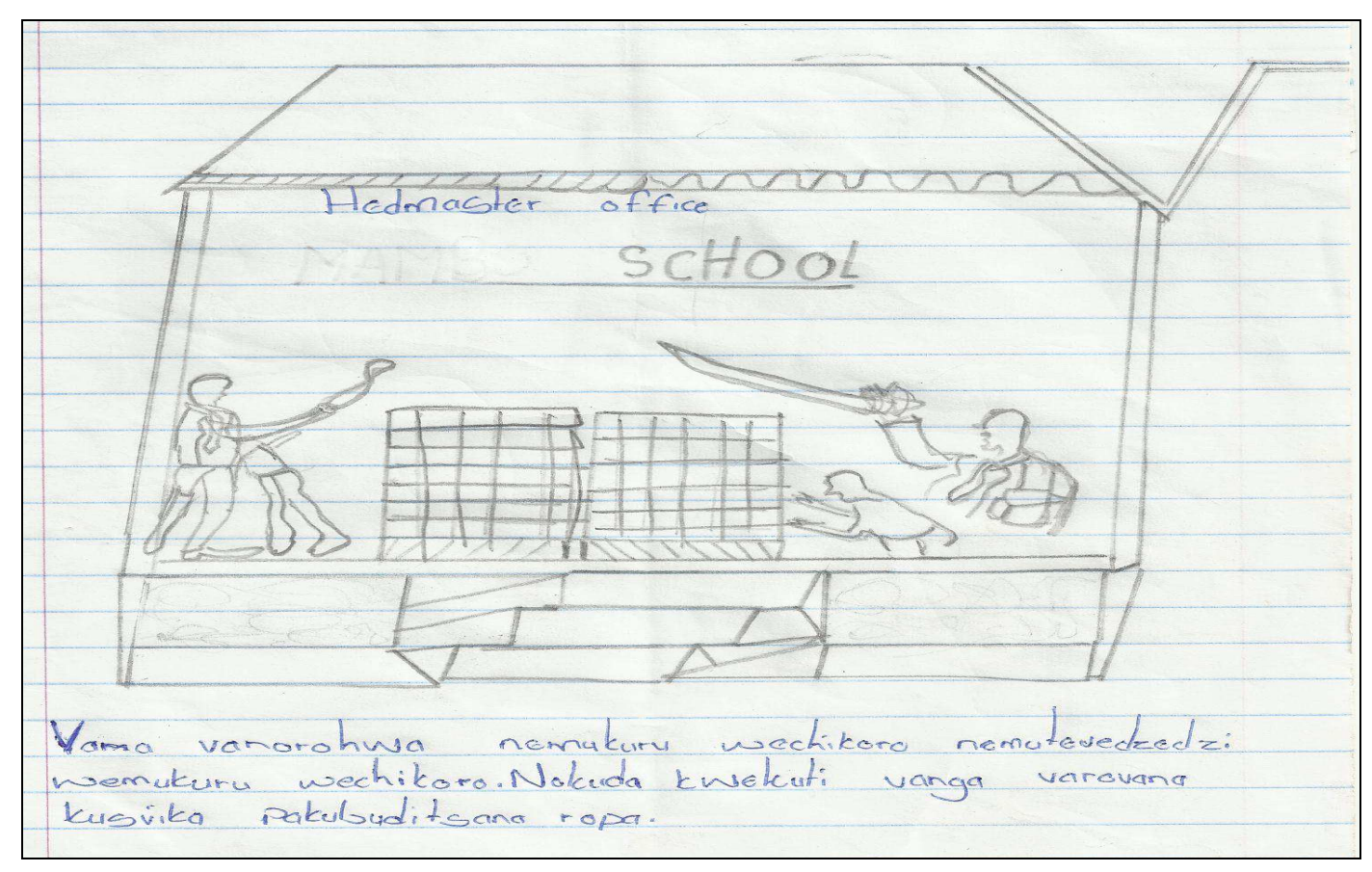

Figure 2. The school head in his office and the deputy disciplining 2 violent students who fought.

The inscription in figure 2 when translated literally refers to the school head that is beating up a student (in right corner) and the deputy (in left corner). The two students got involved in a scuffle leading to a terrible fist fighting until both were bleeding.

Apologising to one another was suggested by two participants who thought this might be a way of managing violent behaviour among students (figure 3). Student D had this to say;

'Kana ndikakanganisa ndinofanira kugara pasi ndokumbira ruregerero’

Student D was only saying that if one is involved in whatever act or behaviour likely to cause a misunderstanding, he or she must always apologise.

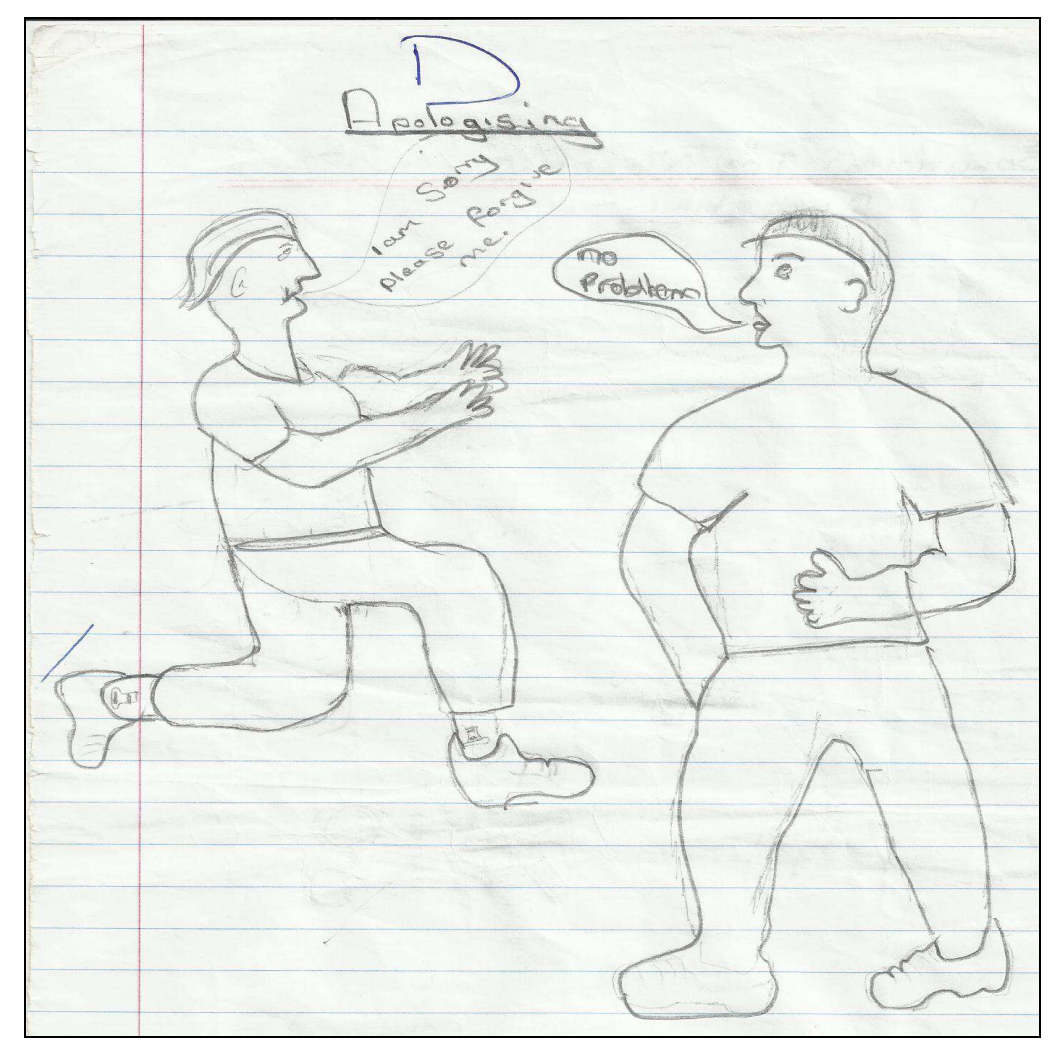

Figure 3. A student kneeling down to a fellow student in apology. 
Five participants seem to suggest other forms of punishment as the best solution to manage violent behaviour. Different kinds of punishment that were suggested by those participants included digging in the garden and cutting down trees (figure 4). The participants said the following during the focus group discussion;

'Munhu ngaatemeswe muti kana kuchereswa gomba ozofutsira`
The participants were saying that students involved in violent acts must be punished, for example, must dig a pit and eventually close it up again. In the drawing, the violent student is cutting down a tree as a form of punishment. The participants believed that if one is given such punishment which is hard labour, he or she will not repeat that. Other students will not engage in violent acts in fear of being punished as well if they see that.

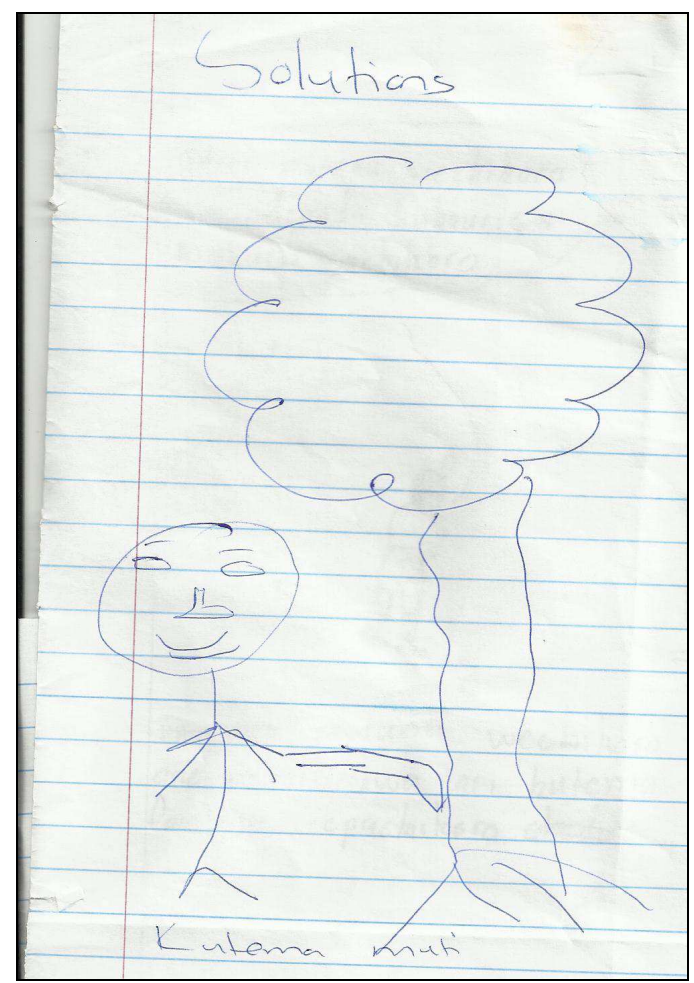

Figure 4. A student cutting down a tree as a form of punishment.

\section{Discussion and Conclusion}

The participants were some of the violent students in the school. They suggested different ways in which they thought would minimize or eliminate violent behaviour among students. Guidance and Counselling lessons, apologising to one another, punishment and involvement of parents and police were some of the ways suggested by the students.

Involvement of parents was suggested as part of the solution. Parents should be informed when their child is involved in any violent behaviour. The parents are to be involved in the child's activities even at home. The parent therefore would always be there to support the child both at home and at school. [6, 7] opined that involvement of the family is important as this will enhance the effectiveness of school based efforts. This suggests that if parents are involved it will be easy for the school to enforce their rules as the parents will support them. In the process this will reduce the chances of violent behaviour at school. If the parents are involved they will monitor their child's behaviour at home and this will shape the behaviour of the child. Such children will be able to distinguish between wrong and right. If a child gets proper attention and love from the parents he or she might not be involved in violent behaviours. Teachers and parents' communication should be enhanced and allow both sides to work together as a team so that rules, norms and values are the same at school and at home.

Involvement of the police might be a solution to violence reduction among students. Most of the participants during the focus group discussions agreed that sometimes it is necessary to involve the police so that anyone involved in violent behaviour is disciplined by the police. One of the participants confessed that she was once sent to be disciplined by the police a month prior to this research after she was involved in a violent fight with another female student. This student was saying that she does not want to have that same experience again hence she will not engage in any violent behaviour. Involvement of police might reduce violent behaviour among students in the sense that most of the participants will choose not to be involved in any violent acts because they will be afraid of being disciplined by the police or even send to jail. Such management styles will in the long run curtail violence in schools. 
Guidance and counselling lessons were suggested as a way that could be used to manage and reduce violent behaviour among students. The participants believed that counselling is essential as it might enlighten the students about violence, its negative effects and the school position regarding it. One might choose not to be involved and those who are already involved might decide to change their misbehaviour hence in the process this might be a suitable way to reduce and manage violent behaviour in schools. [10] suggested that there is need to refer students with aggressive behaviour to counselling officers. Two participants pointed out that the school head should discipline those who exhibit violent behaviour. The participants from the discussions seem to argue that if a student is aware that he or she will be disciplined, he or she will not exhibit violent behaviour. There is need for the school to enhance guidance and counselling lessons so that the students might benefit from them.

Just to say 'I am sorry' was seen to be a simple way that could be used to reduce violent behaviour in the school. Figure 3 shows a male student kneeling down and asking for forgiveness from a fellow student. Apologising actually reduce one's anger hence will not become violent. Therefore the schools must indoctrinate a culture of tolerance and being apologetic to minimise violent behaviour among students Thus initiative must be driven by both the school and students if it is to be successful. Participants pointed out that those who exhibit violent behaviour must be punished. The participants believed that if students are aware that they will be punished, they might not exhibit any violent behaviour and those who are violent if they are punished heavily will not repeat that misbehaviour. The following are some of the forms of punishment that were suggested by the participants; digging in the garden, cutting down trees and sweeping the school yard after school hours. Sometimes there is need for the teachers to use positive reinforcement and disciplinary measures that are educative and not punitive [13].

The school must have a clear policy on how to effectively deal with violent behaviour among students. The school must engage parents and guardians through School Development Associations (SDA) meetings and workshops in an endeavour to adopt and implement collaborative initiatives towards reduction or elimination of violent incidences among students. There must be effective dual communication between school authorities and parents in order to enhance the spirit of co-operation and teamwork to deal with indiscipline and instil among students some rules, norms and values of tolerance at home and at school. The school must indoctrinate a culture of tolerance and remorsefulness among students. There must also be community engagement towards violence reduction.

The curriculum for pre-service training of teachers should include more information regarding anger management in students so that teachers will be equipped with relevant knowledge regarding anger management. Following the ethos and spirit of the findings of this study, it is possible to eliminate violence in schools.
The study was limited to one school, hence more studies can be done which include more schools in order to generalise the findings to a larger scale.

\section{References}

[1] Gudyanga, E., Matamba, N., \& Gudyanga, A. (2014). Visual participatory approach to violent behaviour amongst Zimbabwe students: Forms and prevalence. Asian Social Science, 10(10), 30-40.

[2] Gudyanga, E., Gudyanga, A. \& Matamba, N. (2014). Aetiology of students' violent behaviour: The case of an urban school in Zimbabwe. Global Journal of Interdisciplinary Social Sciences, (in press)

[3] Amado, J. and Freire, I. (2003). Violent prevention in schools using the internet: A European perspectives. Retrieved from http://www.bullying-in-school.Info/en/contents/factsfiguring/sbv- prevention.html.

[4] Basch, C. (2011). Aggression and violence and the achievement gap among urban minority youth. Journal of School Health, 81(10), 619-625.

[5] Cohen, J , Mccabe, E. , Mitchell, N. and Pickeral, T. (2009) School climate: Research, policy, practice and teacher education. American Psychological Association, School Psychology Quarterly, 27(3), 154- 169.

[6] Drolet, M. , Paquin, M. and Soutyrine, M. (2007). Strengths based approach and coping strategies used by parents whose young children exhibited violent behaviour: Collaborative between school and parents. Child Adolescent Social Work Journal, 24 437-453.

[7] SACE. (2011). School based violence report: An overview of school based violence in South Africa. Retrieved from http://www.sace.org.za/upload/files/School\%20Based\%20Viol ence\%20Report- 2011.pdf

[8] Paterson, C. (2012). Classroom behaviour of children living in contexts of adversity (Unpublished Master of Education thesis). Faculty of Education, Stellenbosch University, South Africa.

[9] Smallhood, D. (2003). Defusing children's violent behaviour. New Jersey: EBSCO.

[10] Smallhood, D. and Kern, E. (2006). Defusing violent behaviour in schools. New Jersey: Philadelphia College of Osteopathic Medicine.

[11] Thomas, S. and Smith, H. (2004). School connectedness, anger behaviours and relationship of violent and non violent American youths. Psychiatric Care, 40(4), 29-37.

[12] Morais, P. and Meier, C. (2010). Disruptive behaviour in the foundation phase of schooling. South African Journal of Education, 30(1), 41-57.

[13] Rayment, T. (2006). Managing boy`s behaviour. New York: MPG Books Limited.

[14] Aluede, O. (2011). Managing bullying problems in Nigerian secondary schools: Some counselling intervention for implementation. The African symposium, Online Journal of the African Educational Research Network, 11(1), 138-144. 
[15] Burton, P. (2007). Dealing with school violence I South Africa. Centre of Justice and Crime, (4), 1-8.

[16] Mitchell, C. (2011). Doing visual research. London: Sage publications.

[17] Denzin, N.K. \& Lincoln, Y.S. (2003). Collecting and interpreting qualitative materials. London: Sage publications.

[18] Moletsane, R. De Lange. N. Mitchell, C., Stuart, J. \& Buthelezi, T. (2007). Photovoice as an analytical and activist tool in the fight against HIV and AIDS stigma in a rural KwaZulu-Natal school. South African Journal of Child and Adolescent Mental Health, 19(1), 19-28.
[19] Deacon, S. (2000). Creativity within qualitative research on families: New ideas for old methods. The qualitative Report, 3(4) 1-6.

[20] Lorenzo, L. and Kolb, B. (2009). Involving the public through visual participatory research method. Health expectations, 12(3), 262-274.

[21] Guillemn, M. (2004). Understanding illness: Using drawing as research methodology. New York: Routledge. 